Ryszard CZERNIAWSKI ${ }^{1}$

Szkoła Wyższa Psychologii Społecznej, Warszawa

\title{
Krajowy mechanizm prewencji - funkcje i zadania Rzecznika Praw Obywatelskich
}

Z godnie z art. 1 ust. 4 ustawy z dnia 15 lipca 1987 r. o Rzeczniku Praw Obywatelskich ${ }^{2}$, Rzecznik wykonuje funkcje organu wizytującego do spraw zapobiegania torturom i innemu okrutnemu, nieludzkiemu lub poniżającemu traktowaniu albo karaniu (krajowy mechanizm prewencji) w rozumieniu Protokołu fakultatywnego do Konwencji w sprawie zakazu stosowania tortur oraz innego okrutnego, nieludzkiego lub poniżającego traktowania albo karania, przyjętego przez Zgromadzenie Ogólne Narodów Zjednoczonych w Nowym Jorku dnia 18 grudnia 2002 r. $^{3}$

Wskazane powyżej zadania Rzecznika Praw Obywatelskich związane są z ratyfikacją przez Polskę Protokołu Fakultatywnego do Konwencji w sprawie zakazu stosowania tortur oraz innego okrutnego, nieludzkiego lub poniżającego traktowania albo karania (tzw. OPCAT), przyjętego przez Zgromadzenie Ogólne Narodów Zjednoczonych w Nowym Jorku w dniu 18 grudnia 2002 r. Dokonana ona została przez Prezydenta RP 2 września 2005 r. na podstawie ustawy z dnia 8 lipca 2005 r. o ratyfikacji tegoż dokumentu ${ }^{4}$.

W myśl art. 1 protokołu jego celem było ustanowienie systemu regularnych wizyt w celu zapobiegania torturom oraz innemu okrutnemu, nieludzkiemu lub poniżającemu traktowaniu albo karaniu przeprowadzanych przez niezależne międzynarodowe i krajowe organy w miejscach, gdzie przebywają osoby pozbawione wolności. W myśl z kolei art. $3 \mathrm{w}$ celu zapobiegania torturom i innemu okrutnemu, nieludzkiemu lub poniżającemu traktowaniu albo karaniu każde państwo będące stroną tej umowy tworzy, wyznacza bądź utrzymuje już istniejący jeden lub

1 Dr prawa, adiunkt na Wydziale Prawa i Nauk Społecznych Szkoły Wyższej Psychologii Społecznej, zastępca Rzecznika Praw Obywatelskich.

2 Dz. U. 2001, Nr 14, poz. 147 t.j. z późn. zm.

3 Dz. U. 2007, Nr 30, poz. 192.

4 Dz. U. 2005, Nr 150, poz. 1253. 
kilka krajowych organów wizytujących. Organy te zostały w oficjalnym tłumaczeniu protokołu nazwane „krajowym mechanizmem prewencji”, co wprawdzie oddaje cel działania, ale z punktu widzenia chociażby lingwistyki o logice nie wspominając nie wydaje się najwłaściwszym rozwiązaniem. Tym niemniej protokół przewidywał powołanie także „międzynarodowego mechanizmu prewencji”. Zgodnie zaś z art. 4 ust. 1 przez fakt związania Protokołem każde państwo będące jego stroną zezwala na przeprowadzanie wizyt przez obydwa „mechanizmy” w jakimkolwiek miejscu pozostającym pod jego jurysdykcją i kontrolą, gdzie przebywają lub mogą przebywać osoby pozbawione wolności na podstawie polecenia organu władzy publicznej bądź za jego namową, zgodą lub przyzwoleniem.

W przypadku natomiast krajowych mechanizmów prewencji art. 17-20 Protokołu przewidywały, że każde państwo będące jego stroną utrzyma, wyznaczy bądź utworzy, najpóźniej w okresie roku od wejścia w życie niniejszego protokołu bądź też od jego ratyfikacji lub przystąpienia do niego, jeden lub kilka niezależnych krajowych mechanizmów prewencji w celu zapobiegania torturom na poziomie krajowym oraz zagwarantuja funkcjonalną niezależność krajowych mechanizmów prewencji, jak również niezależność ich personelu. Ciążyły też na nich inne obowiązki a w szczególności przyznania organom wskazanym jako krajowe mechanizmy prewencji uprawnień co najmniej do:

- regularnego sprawdzania sposobu traktowania osób pozbawionych wolności w miejscach zatrzymań, w celu wzmocnienia, jeśli to niezbędne, ich ochrony przed torturami oraz innym okrutnym, nieludzkim lub poniżającym traktowaniem albo karaniem;

- przedstawiania rekomendacji właściwym władzom w celu poprawy traktowania oraz warunków osób pozbawionych wolności i zapobiegania torturom oraz innemu okrutnemu, nieludzkiemu lub poniżającemu traktowaniu albo karaniu, mając na uwadze odpowiednie normy Organizacji Narodów Zjednoczonych;

- przedstawiania propozycji i uwag odnośnie do obowiązujących oraz projektowanych przepisów prawnych;

- dostępu do wszystkich informacji dotyczących liczby osób pozbawionych wolności w miejscach zatrzymań, jak również liczby miejsc i ich położenia;

- dostępu do wszystkich informacji dotyczących traktowania tych osób, jak również warunków ich zatrzymania;

- dostępu do wszystkich miejsc uwięzienia, ich instalacji i urządzeń; 
- możliwości odbywania prywatnych rozmów bez świadków z osobami pozbawionymi wolności, bądź osobiście, bądź poprzez tłumacza, jeśli uznane to zostanie za niezbędne, jak również z każdą inną osobą, co do której krajowy mechanizm prewencji uzna, że może ona dostarczyć stosownych informacji;

- swobody wyboru miejsc, które zechce odwiedzić, oraz osób, z którymi zechce odbyć rozmowy.

Jednocześnie na mocy art. 21 Protokołu żadna władza lub funkcjonariusz nie nakaże, nie zastosuje, nie pozwoli ani nie dopuści do stosowania jakiejkolwiek sankcji przeciwko jakiejkolwiek osobie lub organizacji, za przekazanie krajowemu mechanizmowi prewencji jakiejkolwiek informacji, prawdziwej bądź fałszywej, i żadna taka osoba lub organizacja nie poniesie żadnego uszczerbku w jakikolwiek inny sposób. Same poufne informacje zebrane w ramach funkcjonowania krajowych mechanizmów prewencji są objęte tajemnicą, a żadne osobiste dane nie zostaną opublikowane bez wyraźnej zgody osoby, której one dotyczą.

Wykonywanie przez Rzecznika Praw Obywatelskich funkcji organu wizytującego do spraw zapobiegania torturom i innemu okrutnemu, nieludzkiemu lub poniżającemu traktowaniu albo karaniu (tzw. krajowego mechanizmu prewencji) w rozumieniu Protokołu Fakultatywnego do Konwencji w sprawie zakazu stosowania tortur oraz innego okrutnego, nieludzkiego lub poniżającego traktowania albo karania powierzone zostało ustawą z dnia 18 sierpnia 2011 r. $^{5}$ nowelizującą ustawę o Rzeczniku Praw Obywatelskich. Ustawa ta przewidywała nadto, że Rzecznik regularnie sprawdza sposób traktowania osób pozbawionych wolności i podczas wykonywania powyższego zadania ma również prawo:

1) rejestrować dźwięk lub obraz w miejscach, w których przebywają oso-

by pozbawione wolności, za zgodą osób, które będą rejestrowane;

2) odbywać spotkania z osobami pozbawionymi wolności, bez obecności innych osób, a także z innymi osobami, co do których uzna, że mogą dostarczyć istotnych informacji.

Zarejestrowany obraz i dźwięk winien być przy tym przechowywany w Biurze Rzecznika Praw Obywatelskich, w pomieszczeniach zabezpieczonych przed dostępem osób nieupoważnionych, przez okres niezbędny w danej sprawie, jednak nie dłużej niż przez 10 lat, a udostępnienie może nastąpić na rzecz osoby, która została zarejestrowana, a także jej

5 Dz. U. 2011, Nr 222, poz. 1320. 
przedstawicielowi ustawowemu lub pełnomocnikowi. Rzecznik został także upoważniony (art. 17c) do przetwarzania wszelkich informacji, w tym danych osobowych, o których mowa w art. 27 ust. 1 ustawy z dnia 29 sierpnia 1997 r. o ochronie danych osobowych w zakresie niezbędnym do realizacji swoich ustawowych zadań.

W uzasadnieniu do projektu ustawy stwierdzono, że za takim rozwiązaniem przemawiał w szczególności wymóg niezależności krajowego mechanizmu prewencji przewidziany w art. 18 ust. 1 Protokołu, którego nie spełniałby organ funkcjonujący w ramach administracji publicznej ${ }^{6}$.

Jak wynika z Raportu Rzecznika Praw Obywatelskich z działalności krajowego mechanizmu prewencji w roku 2011, Rzecznik Praw Obywatelskich działający w tym zakresie swoich obowiązków przeprowadził łącznie 87 wizytacji zapobiegawczych oraz 2 wizytacje mające na celu sprawdzenie stanu realizacji uprzednio wydanych zaleceń. Najwięcej wizytacji odbyło się w: Pomieszczeniach dla osób zatrzymanych przy jednostkach organizacyjnych Policji (27 jednostek). Przeprowadzono je także w Zakładach Karnych (12), Młodzieżowych Ośrodkach Wychowawczych (12), Policyjnych Izbach Dziecka (10), Młodzieżowych Ośrodkach Socjoterapii (7), Izbach Wytrzeźwień (5), Izbach Zatrzymań Żandarmerii Wojskowej (4), Aresztach Śledczych (4), Zakładach Poprawczych (2), Schroniskach dla Nieletnich (2), Zakładach Poprawczych i Schroniskach dla Nieletnich funkcjonujących łącznie (2), Domach Pomocy Społecznej (2) ${ }^{7}$. Stosowanie bowiem do treści art. 4 OPCAT przez miejsce zatrzymań rozumie się jakiekolwiek miejsce pozostające pod jurysdykcją i kontrolą danego państwa, gdzie przebywają lub mogą przebywać osoby pozbawione wolności na podstawie polecenia organu władzy publicznej bądź za jego namową, zgodą lub przyzwoleniem. Pozbawienie wolności oznacza zaś jakąkolwiek formę zatrzymania lub uwięzienia bądź umieszczenia osoby w publicznym lub prywatnym miejscu odosobnienia, którego osobie tej nie wolno z własnej woli opuszczać, na mocy polecenia jakiejkolwiek władzy sądowej, administracyjnej lub innej.

Zgodnie z przyjętą metodologią grupa wizytacyjna składa się zazwyczaj z 4 osób, z których połowa zapoznaje się z terenem i obiektami

6 Szerzej uzasadnienie projektu ustawy zawarte w druku Sejmu VI Kadencji nr 4044.

7 Raport Rzecznika Praw Obywatelskich z działalności krajowego mechanizmu prewencji w roku 2011, s. 25-26. 
placówki, a pozostałe przeprowadzają indywidualne rozmowy z osobami pozbawionymi wolności. Czas wizytacji wnosi od 1 do 3 dni, a zależy od wielkości jednostki i zastanych na miejscu problemów, zazwyczaj trwa od 1 do 3 dni. Po każdej wizytacji sporządzany jest raport. Zawiera on informacje dotyczące m.in. warunków bytowych, stanu przestrzegania praw osób przebywających w danym zakładzie, zagadnień związanych z wyżywieniem, opieką medyczną czy korespondencją i widzeniami. Raporty sporządzane w następstwie wizytacji wysyłane są do dyrektora wizytowanej placówki, organów nadrzędnych, sędziego sprawującego nadzór nad jednostką, Helsińskiej Fundacji Praw Człowieka oraz Koalicji „Porozumienie na rzecz wprowadzania OPCAT”.

Jak wynika z przedstawionej Sejmowi i Senatowi informacji o działalności Rzecznika Praw Obywatelskich w roku 2011 oraz o stanie przestrzegania wolności i praw człowieka i obywatela ${ }^{8}$ wizytacje przeprowadzane w ramach Krajowego Mechanizmu Prewencji muszą być regularne, a więc dokonywane z odpowiednią częstotliwością. W Polsce funkcjonuje około 1800 jednostek podlegających wizytacjom, wymagałoby to 38 etatów, tymczasem obecnie zadanie to wykonuje 7 osób, dlatego w 2011 r. urząd Rzecznika mógł przeprowadzić tylko 89 wizytacji, bo na tyle pozwalały środki finansowe. Warto zauważyć, że przy zachowaniu tej intensywności wizytacji jednostka objęta Mechanizmem byłaby więc wizytowana raz na dwadzieścia lat. Opisany stan rzeczy jest spowodowany ciagłym niedofinansowaniem Krajowego Mechanizmu Prewencji, bo mimo że Rzecznik w kolejnych składanych do parlamentu projektach budżetu BRPO przewidywała wzrost nakładów na ten cel, nie był on akceptowany $\mathrm{w}$ toku prac parlamentarnych. W rezultacie nie można uznać, że w 2011 roku Polska w pełni wywiązała się z przyjętego na siebie w umowie międzynarodowej zobowiązania do zapewnienia niezbędnych środków na działania w ramach Krajowego Mechanizmu Prewencji.

Zgodnie z informacją Rzecznika Praw Obywatelskich podczas wizytacji przeprowadzonych w 2011 r. nie dostrzeżono sytuacji, które świadczyłyby o stosowaniu tortur na terenie Rzeczypospolitej Polskiej. Należy to zaznaczyć, że zgodnie z art. 1 Konwencji ONZ w sprawie zakazu stosowania tortur przez tortury rozumie się każde działanie, którym jakiejkolwiek osobie umyślnie zadaje się ostry ból lub cierpienie, fizyczne

8 Informacji o działalności Rzecznika Praw Obywatelskich w roku 2011 oraz o stanie przestrzegania wolności i praw człowieka i obywatela, BRPO 2012, s. 18-19. 
bądź psychiczne, w celu uzyskania od niej lub od osoby trzeciej informacji lub wyznania w celu ukarania jej za czyn popełniony przez nią lub osobą trzecią, albo o którego dokonanie jest ona podejrzana, a także w celu zastraszenia lub wywarcia nacisku na nią lub trzecią osobę albo w jakimkolwiek innym celu wynikającym z wszelkiej formy dyskryminacji, gdy taki ból lub cierpienie powodowane są przez funkcjonariusza państwowego lub inną osobę występującą w charakterze urzędowym lub z ich polecenia albo za wyraźną lub milczącą zgodą.

Na podstawie przeprowadzonych wizytacji przedstawiciele Rzecznika Praw Obywatelskich wykonujący swoje obowiązki w ramach Krajowego Mechanizmu Prewencji stwierdzali jednak, że w miejscach pozbawienia wolności dochodzi do sytuacji, które zgodnie należy uznać za poniżające lub mające charakter nieludzkiego traktowania albo karania w rozumieniu norm KMP. Uwagi sformułowane w wyniku wizytacji jednostek penitencjarnych dotyczyły głównie kwestii potrzeby renowacji oddziałów mieszkalnych, zabudowy kącików sanitarnych oraz zapewnienia poczucia intymności osobom pozbawionym wolności. W zakładach karnych i aresztach śledczych powtarzał się problem przeprowadzania badań medycznych osadzonych w obecności funkcjonariusza Służby Więziennej, a tym samym naruszania prawa do intymności i poszanowania godności osadzonych oraz prawa do tajemnicy medycznej. Z krytyczną oceną warunków bytowych wiąże się kwestia przeludnienia jednostek penitencjarnych. Do celów mieszkalnych adaptowane były świetlice, izby chorych, a w niektórych przypadkach nawet cele do wykonywania kary dyscyplinarnej w postaci umieszczenia w celi izolacyjnej oraz cele przeznaczone dla tzw. osadzonych „niebezpiecznych”. Pozyskiwanie dodatkowych miejsc zakwaterowania odbywało się więc kosztem oferty zajęć kulturalno-oświatowych, z których mogłaby korzystać większość osadzonych ${ }^{9}$.

W ocenie przedstawicieli Rzecznika Praw Obywatelskich funkcjonariusze Służby Więziennej generalnie traktowali osoby pozbawione wolności z poszanowaniem ich godności. Odnotowano jednak przypadki poniżających form traktowania osadzonych podczas stosowania środka przymusu bezpośredniego w postaci umieszczenia w celi zabezpieczającej. W przypadku jednostek dla nieletnich najbardziej niepokojące były niedopuszczalne formy karania wychowanków, które zdaniem osób

9 Informacja..., op. cit., BRPO 2012, s. 19. 
wizytujących w niektórych przypadkach, były nieludzkim i poniżającym traktowaniem. W placówkach pojawiały się również zarzuty stosowania siły fizycznej przez ich pracowników.

W funkcjonowaniu pomieszczeń dla osób zatrzymanych jednostek organizacyjnych Policji stwierdzono nieprawidłowości polegające między innymi na nieinformowaniu zatrzymanych o przysługujących im prawach. W izbach wytrzeźwień pracownicy wykonujący zadania Krajowego Mechanizmu Prewencji stwierdzili - podobnie jak w latach ubiegłych - przypadki niezgodnego z prawem stosowania środków przymusu bezpośredniego, w tym np. braku kontroli przez personel stanu zdrowia unieruchomionych pacjentów. W przypadku zakładów poprawczych i schronisk dla nieletnich pracownicy Biura Rzecznika Praw Obywatelskich stwierdzili m.in., że w katalogach środków dyscyplinarnych wizytowanych placówek wśród kar znajdowała się również kara w postaci przeniesienia wychowanka do innej placówki, co naruszało europejskie reguły dla młodocianych przestępców objętych sankcjami lub środkami alternatywnymi. Mając na uwadze standardy międzynarodowe, ustalenia KMP oraz stanowiska dyrektorów wizytowanych placówek, Rzecznik Praw Obywatelskich w dniu 23 września 2011 r. skierowała wystapienie $^{10}$ do Ministra Sprawiedliwości w sprawie stosowanej w niektórych zakładach poprawczych kary przeniesienia wychowanka do innej placówki. Wątpliwości Rzecznika wzbudził ponadto fakt, iż podstawą stosowanych w zakładach poprawczych kar nie są regulacje ustawy z dnia 26 października 1982 r. o postępowaniu w sprawach nieletnich, lecz rozporządzenie w sprawie zakładów poprawczych i schronisk dla nieletnich. W odpowiedzi na wystapienie Rzecznika Praw Obywatelskich, Minister Sprawiedliwości poinformował m.in., że procedura obowiązująca przy przenoszeniu wychowanka do innego zakładu uniemożliwia arbitralne podejmowanie decyzji przez dyrektora placówki oraz gwarantuje wychowankowi przestrzeganie jego praw. Nie podzielając tego poglądu, Rzecznik Praw Obywatelskich złożyła wniosek do Trybunału Konstytucyjnego o stwierdzenie niezgodności szeregu regulacji zawartych w rozporządzeniu Ministra Sprawiedliwości z dnia 17 września 2001 r. w sprawie zakładów poprawczych i schronisk dla nieletnich z art. $95 \S 3$ ustawy z dnia 26 października 1982 r. o postępowaniu w sprawach nieletnich z art. 92 ust. 1 zd. 1 Konstytucji Rzeczpospolitej Polskiej.

10 RPO-672825-VII/11. 
Należy wskazać, że, jak wynika z informacji Rzecznika Praw Obywatelskich, szereg rekomendacji wydanych w wyniku dokonanych czynności, zostało uwzględnionych przez kierownictwo poszczególnych placówek niezwłocznie w następstwie wizytacji. Realizacja tych, które wymagają odpowiednich nakładów finansowych, jest monitorowana przez pracowników Biura RPO.

W opinii Rzecznik Praw Obywatelskich ${ }^{11}$ konwencja w sprawie zakazu stosowania tortur oraz innego okrutnego, nieludzkiego lub poniżającego traktowania albo karania, przyjętego przez Zgromadzenie Ogólne Narodów Zjednoczonych w Nowym Jorku dnia 18 grudnia 2002 r. nie definiuje pojęć nieludzkiego lub poniżającego traktowania, jednak niezwykle bogate orzecznictwo Europejskiego Trybunału Praw Człowieka dookreśliło w pewnym stopniu ich znaczenie. Zgodnie z linią orzeczniczą Trybunału traktowanie jest poniżające, gdy powoduje poczucie strachu i upokorzenia prowadzące do upodlenia. W rezultacie może dojść do załamania fizycznego i psychicznego. Każda tortura jest nieludzkim i poniżającym traktowaniem, a nieludzkie traktowanie - również poniżające.

\section{National preventive mechanism - the functions and tasks of the Commissioner for Civil Rights Protection of Poland}

\section{Summary}

The paper points out that the Commissioner for Civil Rights Protection of Poland performs the functions of a visiting body for the prevention of torture and other cruel, inhuman or degrading treatment or punishment (national preventive mechanism) as understood in the Optional Protocol to the Convention against Torture and Other Cruel, Inhuman or Degrading Treatment or Punishment, adopted by the General Assembly of the United Nations in New York on December 18, 2002.

11 Op. cit., s. 9. 